\title{
UPAYA MENINGKATKAN HASIL BELAJAR IPA MATERI DAUR AIR MELALUI MODEL PEMBELAJARAN PROBLEM BASED LEARNING
}

\author{
Reni Setiowati \\ SD N Bojongsari, Banyumas, Indonesia \\ Email: setiowatireni@gmail.com
}

\begin{abstract}
Abstrak. The research was supported by the low learning outcome on science subject for fifth B grade SD Negeri 1 Bojongsari student. This is evidenced from the low cognitive evaluation based on the evaluation of data subjects of natural science that shows that there are still many students who have not attained mastery learning. The research was aimed at improving students' natural science learning outcome on the material of watercycle through Problem Based learningat fifth grade student of elementari school. The subjects were the students of fith grade SD Negeri 1 Bojongsari, there were 24 students, 10 male and 14 female ones. This classroom action research was conducted in two cycles. The data were collected from test and observation.Evaluation test was used to collect the data of cognitive aspect of written tests conducted at the end of each cycle. Affective and phsycomotoric evaluation worksheet was used to collect the data of affective and phsycomotoric aspect. The result shown the achievement mean in cycle I was 68,3 and then increased to 81,67 in cycle II. The result of affective aspect the percentage in cycle I was $70,42 \%$ and increased to $85,62 \%$. The result of phsycomotoric aspect the percentage in cycle I was $80,03 \%$ and increased to $90,1 \%$. Finally, it can be drawn a conclusion that Problem Based Learning can improve students' natural science learning outcome in the graderVB SD Negeri 1 Bojongsari.
\end{abstract}

Keywords: learning outcome, natural science, Problem Based Learning

\begin{abstract}
Abstrak. Penelitian ini dilatarbelakangi oleh rendahnya hasil belajar siswa pada mata pelajaran IPA di kelas VB SD Negeri 1 Bojongsari.Hal tersebut dibuktikan dari rendahnya hasil belajar aspek kognitif siswa berdasarkan data hasil evaluasimata pelajaran IPA yang menunjukkan bahwa masih banyak siswa yang belum mencapai ketuntasan belajar. Hasil belajar aspek afektif siswa yang rendah ditunjukkan dari kurangnya partisipasi siswa selama proses pembelajaran, sedangkan rendahnya hasil belajar aspek psikomotor siswa ditunjukkan dari kurangnya kemampuan siswa dalam menggunakan alat peraga maupun media pembelajaran. Penelitian ini bertujuan untuk meningkatkan hasil belajar IPA materi daur air pada siswa kelas V di sekolah dasar melalui model pembelajaran Problem Based Learning. Subjek dalam penelitian ini adalah siswa kelas VB SD Negeri 1 Bojongsari yang berjumlah 24 siswa, terdiri dari 10 siswa laki-laki dan 14 siswa perempuan. Penelitian ini merupakan penelitian tindakan kelas yang dilaksanakan dalam dua siklus.Setiap siklus terdiri dari dua pertemuan.Penelitian ini meliputi tahap perencanaan, pelaksanaan tindakan, observasi dan refleksi.Teknik pengumpulan data diperoleh dari tes dan observasi.Data hasil belajar aspek kognitif diperoleh dari tes tertulis yang dilaksanakan pada setiap akhir siklus.Data hasil belajar aspek afektif dan psikomotor diperoleh dengan menggunakan lembar penilaian afektif dan lembar penilaian psikomotor. Berdasarkan hasil penelitian, hasil belajar aspek kognitif siklus I diperoleh rata-rata nilai 68,3 dengan ketuntasan 62,5\% dan siklus II diperoleh rata-rata nilai 81,67 dengan ketuntasan 87,5\%. Hasil belajar aspek afektif diperoleh persentase siklus I sebesar 70,42\% dan siklus II sebesar 85,62\%. Hasil belajar aspek psikomotor diperoleh persentase siklus I sebesar 80,03\% dan siklus II sebesar 90,1\%. Kesimpulan yang diperoleh dari penelitian ini adalah model pembelajaran Problem Based Learningdapat meningkatkan hasil belajar IPA pada siswa kelas VB SD Negeri 1 Bojongsari.
\end{abstract}

Kata kunci: Hasil Belajar, IPA, Model Pembelajaran Problem Based Learning 


\section{LATAR BELAKANG}

Ilmu Pengetahuan Alam (IPA) merupakan salah satu mata pelajaran yang diajarkan di Sekolah Dasar (SD).Pembelajaran IPA sangat diperlukan dalam kehidupan sehari-hari untuk kebutuhan manusia, karena pada dasarnya kehidupan manusia sangat tergantung pada alam dan segala jenis gejala yang terjadi di alam.IPA berhubungan dengan cara mencari tahu tentang alam secara sistematis, sehingga IPA bukan hanya penguasaan kumpulan pengetahuan yang berupa fakta-fakta, konsep-konsep, atau prinsip-prinsip saja, tetapi juga merupakan proses penemuan. Pembelajaran IPA sebaiknya dilaksanakan secara inkuiri ilmiah untuk menumbuhkan kemampuan berpikir, bekerja dan bersikap ilmiah serta mengkomunikasikannya sebagai aspek penting dalam kecakapan hidup.

Permasalahan dalam pembelajaran IPA adalah belum banyaknya kegiatan pembelajaran yang memberikan praktek pengalaman langsung bagi siswa, terbatasnya penggunaan alat peraga atau media pembelajaran sehingga menyebabkan sulitnya siswa memahami konsep dasar IPA.Kenyataan yang ada pada saat di kelas siswa hanya mempelajari IPA dari membaca buku teks dan mendengarkan penjelasan guru saja.Pembelajaran yang dilaksanakan belum memaksimalkan aktivitas belajar siswa yang sesuai dengan tujuan pembelajaran IPA.

Permasalahan pada rendahnya hasil belajar IPA juga terjadi pada siswa kelas VB SD Negeri 1 Bojongsari.Berdasarkan hasil wawancara dengan guru diperoleh informasi dari hasil evaluasi yang menunjukkan bahwa ketuntasan belajar siswa pada mata pelajaran IPA masih rendah. Berdasarkan data tersebut, tercatat bahwa dari 24 siswa hanya terdapat 11 siswa, yakni sebesar $45,8 \%$ yang telah tuntas mencapai Kriteria Ketuntasan Minimum (KKM), sedangkan siswa yang tidak tuntas terdapat 13 siswa, yakni sebesar 54,2\%.

Berdasarkan hasil evaluasi pembelajaran diperoleh informasi yang relevan kemungkinan rendahnya hasil belajar siswa yaitu, pertamapembelajaran lebih berpusat pada guru.Guru hanya menggunakan metode ceramah dari awal sampai akhir pembelajaran, sehingga siswa belum diberi kesempatan untuk ikut berpartisipasi secara aktif dalam kegiatan pembelajaran.Kedua, pembelajaran IPA masih berorientasi pada aspek kognitif saja, guru belum memperhatikan pengembangan kemampuan aspek afektif dan psikomotor siswa. Materi IPA dipelajari siswa hanya dengan hapalan saja, sehingga guru belum memperhatikan kemampuan proses siswa dalam memperoleh pengetahuannya. Ketiga, guru belum menggunakan alat peraga maupun media pembelajaran dalam melaksanakan pembelajaran IPA di kelas, sehingga kemampuan motorik siswa dalam menggunakan alat peraga maupun media pembelajaran masih rendah.

Berdasarkan permasalahan di atas, maka dilakukan penelitian untuk memperbaiki proses dan hasil belajar siswa di kelas $\mathrm{V}$ dengan menggunakan model Problem Based Learning (PBL).Model pembelajaran PBLdipilih karena model ini menuntut keaktifan siswa dalam aktivitas belajar melalui kegiatan pemecahan masalah.Model PBL juga memberikan kesempatan bagi siswa untuk membangun pengetahuannya sendiri melalui kegiatan penyelidikan atau percobaan, sehingga mendorong keterlibatan atau partisipasi siswa dalam pembelajaran.Keterampilan siswa dalam menggunakan alat peraga atau media pembelajaran juga dapat digali melalui kegiatan penyelidikan atau percobaan.

Berdasarkan latar belakang di atas, perumusan masalah dalam penelitian ini, yaitu: (1) Bagaimana penerapan model pembelajaran Problem Based Learning dapat meningkatkan hasil belajar siswa aspek kognitif pada mata pelajaran IPA materi daur air di kelas VB SD Negeri 1 Bojongsari? (2) Bagaimana penerapan model pembelajaran Problem Based Learning dapat meningkatkan hasil belajar siswa aspek afektif pada mata pelajaran IPA materi daur air di kelas VB SD Negeri 
1 Bojongsari? (3) Bagaimana penerapan model pembelajaran Problem Based Learning dapat meningkatkan hasil belajar siswa aspek psikomotor pada mata pelajaran IPA materi daur air di kelas VB SD Negeri 1 Bojongsari?

Tujuan penelitian ini adalah untuk: (1) Meningkatkan hasil belajar siswa aspek kognitif pada mata pelajaran IPA materi daur air melalui model pembelajaran Problem Based Learningdi kelas VB SD Negeri 1 Bojongsari. (2) Meningkatkan hasil belajar siswa aspek afektif pada mata pelajaran IPA materi daur air melalui model pembelajaran Problem Based Learning di kelas VB SD Negeri 1 Bojongsari. (3) Meningkatkan hasil belajar siswa aspek psikomotor pada mata pelajaran IPA materi daur air melalui model pembelajaran Problem Based Learning di kelas VB SD Negeri 1 Bojongsari.Jenis penelitian yang dilaksanakan adalah penelitian tindakan kelas (PTK).PTK ini dilaksanakan dengan cara kolaborasi bersama guru kelas sebagai pelaksana tindakan.

\section{METODOLOGI PENELITIAN}

PTK ini dilaksanakan terdiri dari dua siklus yaitu siklus I dan siklus II.Penelitian yang dilaksanakan di SD Negeri 1 Bojongsari ini menggunakan model penelitian PTK yang dikembangkan oleh Kemmis dan Mc. Taggart (Wiriaatmadja, 2010:66), dengan tahapan setiap siklusnya terdiri dari perencanaan, tindakan, observasi, dan refleksi.Teknik pengumpulan data menggunakan teknik tes dengan memberikan soal uraian dan teknik non tes yaitu dengan menggunakan observasi. Alat pengumpulan data menggunakan lembar evaluasi tes tertulis, lembar penilaian afektif, lembar unjuk kerja, lembar observasi aktivitas guru dan siswa.Analisis data pada penelitian ini yaitu dengan menghitung rata-rata kelas, ketuntasan belajar siswa, sertapersentase hasil penilaian afektif dan unjuk kerja siswa.

\section{HASIL DAN PEMBAHASAN}

Peningkatan hasil belajar IPA materi daur air pada siswa kelas VB di SD Negeri 1 Bojongsari diuraikan dalam pembahasan. Pembahasan hasil-hasil penelitian yaitu sebagai berikut:

\section{a. Peningkatan Hasil Belajar Aspek Kognitif}

Nilai hasil belajar aspek kognitif siswa diperoleh dari hasil evaluasi yang dilaksanakan setiap akhir siklus. Rekapitulasi nilai hasil belajar aspek kognitif siswa dapat dilihat pada tabel dan histogramhasil belajar aspek kognitif berikut ini:

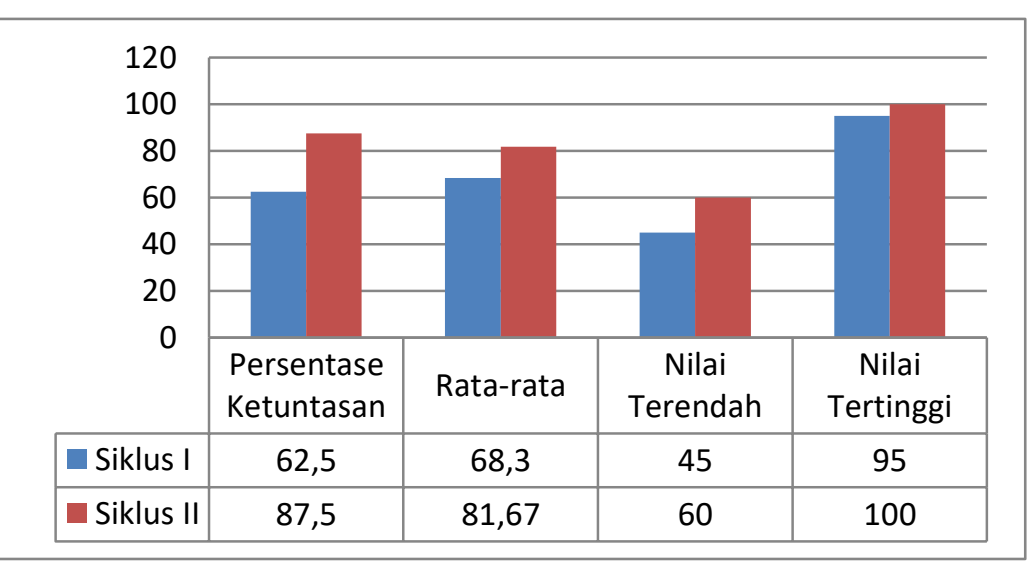




\section{Gambar 1. Histogram Hasil Belajar Aspek Kognitif}

Gambar 1 menunjukkan bahwa terdapat peningkatan hasil belajar aspek kognitif yang tercapai pada siklus II. Peningkatan ketuntasan belajar dari $62,5 \%$ pada siklus I menjadi $87,5 \%$ pada siklus II. Ketuntasan hasil belajar aspek kognitif yang dicapai pada siklus II sudah mencapai indikator keberhasilan dalam penelitian ini.Hal tersebut didukung oleh pendapat
Slameto (2010: 54), bahwa metode mengajar dan metode belajar mempengaruhi belajar seseorang.Peningkatan hasil belajar siswa aspek kognitif juga didukung dari peningkatan aktivitas siswa.Berikut ini adalah tabel dan histogram peningkatan aktivitas siswa.

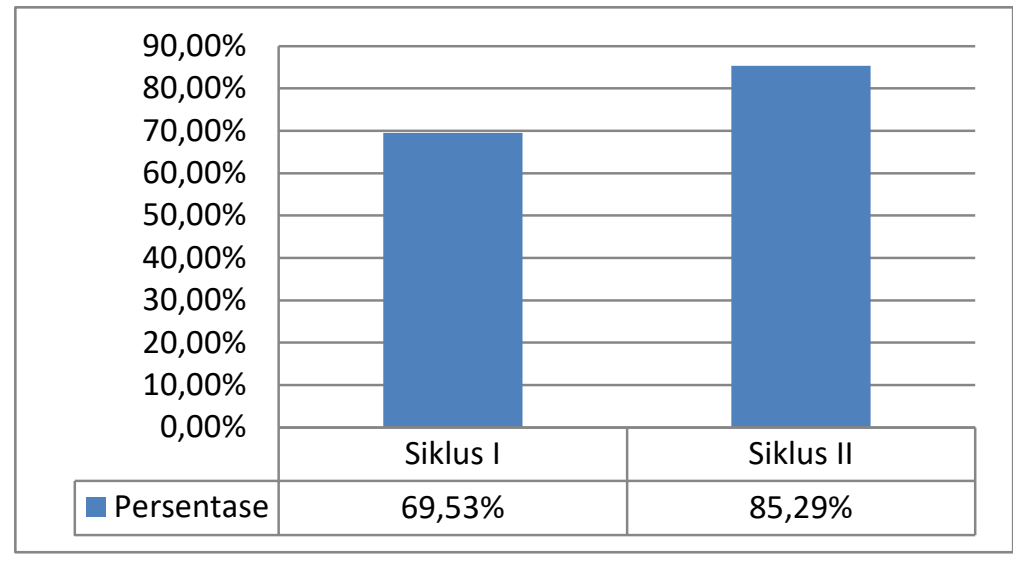

Gambar 2. Histogram Peningkatan Aktivitas Siswa

Gambar 2 menunjukkan terdapat peningkatan aktivitas siswa pada setiapsiklus. Pada siklus I persentase yang diperoleh yaitu $69,53 \%$ dengan kriteria cukup dan meningkat pada siklus II menjadi 85,29\% dengan kriteria baik.

\section{b. Peningkatan Hasil Belajar Aspek Afektif \\ Hasil belajar siswa aspek afektif yang diperoleh dari hasil observasi telah mengalami peningkatan dari siklus I sampai siklus II.Hal ini terlihat pada penilaian hasil belajar aspek afektif yang dilakukan oleh observer pada siklus I dan siklus II.Berikut ini adalah tabel dan histogram hasil belajar siswa aspek afektif.}




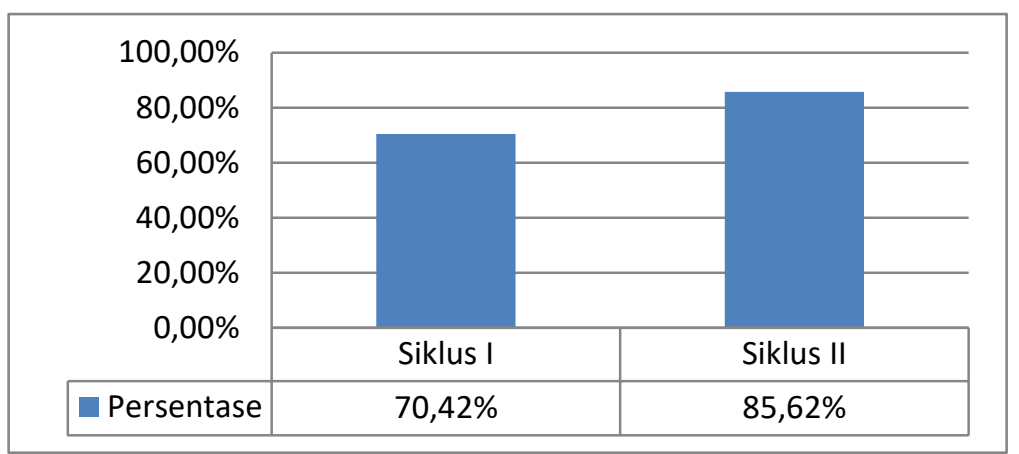

Tabel 3. Histogram Hasil Belajar Aspek Afektif

Gambar 3 menunjukkan bahwa hasil belajar siswa aspek afektif melalui model pembelajaran PBLmengalami peningkatan pada setiap siklusnya. Persentase yang diperoleh pada siklus I yaitu sebesar $70,42 \%$ dan pada siklus II meningkat menjadi $85,62 \%$. Hal ini didukung oleh pendapat dari Shoimin (2014: 132), bahwa model PBL memiliki kelebihan dapat menciptakan terjadinya aktivitas ilmiah pada siswa melalui kerja kelompok dan mendorong siswa memiliki kemampuan untuk komunikasi ilmiah dalam kegiatan diskusi atau presentasi hasil pekerjaan mereka. Pendapat tersebut dapat disimpulkan bahwa model PBL dapat meningkatkan partisipasi siswa melalui aktivitas ilmiah dan komunikasi ilmiah antar siswa.

Peningkatan hasil belajar siswa aspek afektif juga didukung dari peningkatan aktivitas guru pada setiap siklus.Guru dalam melaksanakan pembelajaran IPA dengan menerapkan model PBL melakukan berbagai upaya perbaikan pada tahap refleksi untuk mendorong adanya peningkatan hasil belajar siswa aspek afektif. Berikut ini adalah tabel dan histogram peningkatan aktivitas guru dengan menerapkan model PBL.

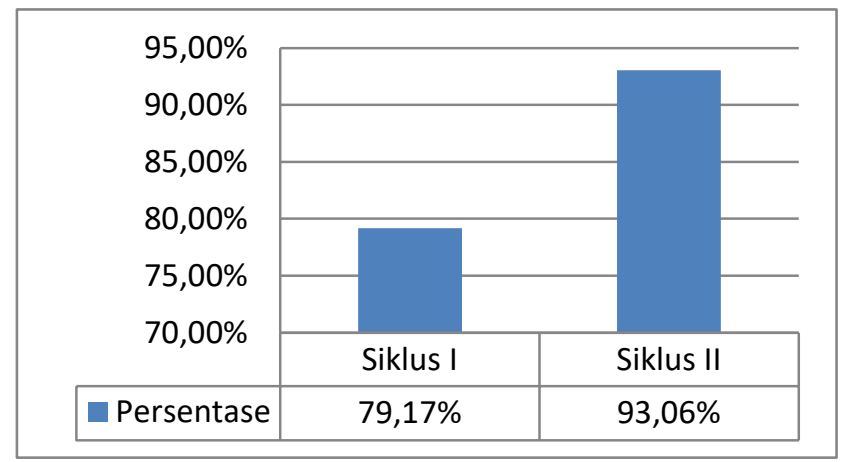

\section{Gambar 4. Histogram Peningkatan Aktivitas Guru}

Gambar 4 menunjukkan bahwa aktivitas guru pada siklus I memperoleh persentase sebesar $79,17 \%$ dan meningkat pada siklus II dengan persentase sebesar 93,06\%. Aktivitas guru yang dilaksanakan selama empat pertemuan dari siklus I sampai siklus II juga selalu mengalami peningkatan pada setiap pertemuan. Hal tersebut menunjukkan bahwa guru selalu melakukan upaya untuk memperbaiki proses pembelajaran. 


\section{c. Peningkatan Hasil Belajar Aspek Psikomotor}

Hasil belajar siswa aspek psikomotor diperoleh dari hasil observasi yang dibantu oleh teman sejawat sebagai observer.Hasil penilaian aspek psikomotor siswa kelas VB SD Negeri 1 Bojongsari mengalami peningkatan dari siklus I ke siklus II.Berikut ini adalah tabel dan histogram hasil belajar aspek psikomotor.

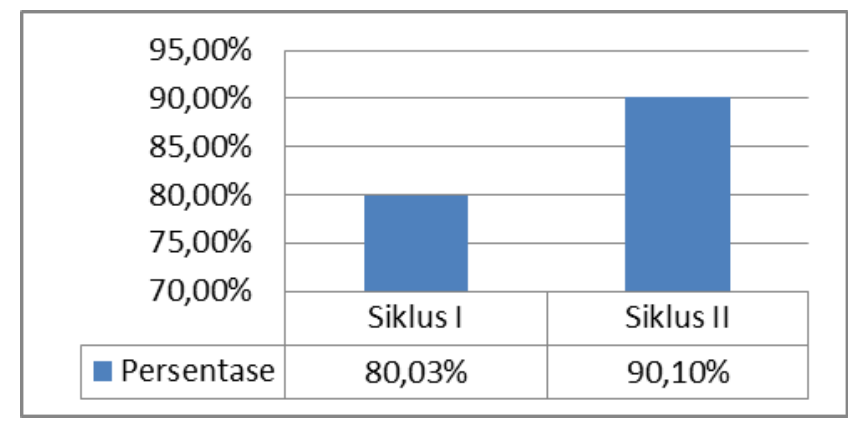

\section{Gambar 5. Histogram Hasil Belajar Aspek Psikomotor}

Gambar 5 menunjukkan bahwa terjadi peningkatan hasil belajar siswa aspek psikomotor pada setiap siklusnya. Persentase yang diperoleh pada siklus I yaitu $80,03 \%$ dengan kriteria baik, kemudian meningkat pada siklus II menjadi 90,1\% dengan kriteria sangat baik. Hal tersebut didukung oleh pendapat Sudjana (2013: 22), bahwa hasil belajar merupakan kemampuan-kemampuan yang dimiliki siswa setelah ia menerima pengalaman belajarnya.Berdasarkan pengalaman yang dilakukan pada siklus I, keterampilan siswa dalam menggunakan alat peraga dalam pembelajaran IPA semakin meningkat.

\section{KELEMAHAN PENELITIAN}

Kelemahan pada penelitian ini adalah hasil belajar siswa aspek afektif yang telah diuraikan di atas diperoleh dengan cara menilai secara langsung partisipasi siswa saat proses pembelajaran. Penilaian hasil belajar aspek afektif yang dilakukan dalam penelitian ini hanya menggunakan lembar penilaian afektif saja dan belum sempat untuk menyebarkan angket partisipasi kepada siswa, walaupun hasil belajar siswa aspek afektif ini dilakukan menggunakan lembar penilaian afektif, namun dalam PTK akan lebih efektif jika dilakukan dengan menyebarkan angket. Penilaian menggunakan lembar penilaian afektif lebih cocok digunakan pada penelitian di kelas rendah, sedangkan di kelas tinggi lebih baik menggunakan angket.Hal itu disebabkan siswa kelas tinggi dipandang sudah mampu untuk mengukur perkembangan hasil belajarnya sendiri.

\section{SIMPULAN DAN SARAN}

Hasil Penelitian Tindakan Kelas (PTK) yang telah dilaksanakan dalam dua siklus di kelas VB SD Negeri 1 Bojongsari materi daur air melalui penerapan model pembelajaran Problem Based Learning (PBL) dapat disimpulkan sebagi berikut:

1. Model pembelajaran PBL dapat meningkatkan hasil belajar aspek kognitif siswa. Hal tersebut ditunjukkan dari peningkatan yang terjadi pada setiap siklusnya. Rata-rata nilai pada siklus I adalah 68,3 dengan ketuntasan belajar klasikal 62,5\%. Pada siklus II mengalami peningkatan dengan rata-rata nilai siswa menjadi 81,67 dan ketuntasan belajar klasikal sebesar $87,5 \%$.

2. Model pembelajaran PBL dapat meningkatkan hasil belajar aspek afektif siswa. Hal ini ditunjukkan adanya peningkatan persentase hasil belajar siswa aspek afektif pada siklus I sebesar 70,42\% dan siklus II sebesar $85,62 \%$.

3. Model pembelajaran PBL dapat meningkatkan hasil belajar aspek psikomotor siswa. Hal ini ditunjukkan adanya peningkatan persentase hasil 
belajar siswa aspek psikomotor pada siklus I sebesar $80,03 \%$ dan siklus II sebesar $90,1 \%$.

Berdasarkan hasil penelitian tindakan kelas yang telah dilaksanakan di kelas VB SD Negeri 1 Bojongsari, maka untuk perbaikan penelitian di masa yang akan datang terdapat beberapa saran yaitu, sebagai berikut:

1. Guru harus selalu mendorong interaksi antar siswa dan memaksimalkan aktivitas belajar siswa agar tujuan pembelajaran dapat tercapai dengan maksimal, karena model PBL menekankan pada aktivitas belajar siswa terkait dengan pemecahan masalah.

2. Guru dalam melaksanakan kegiatan akhir pembelajaran pada langkah melakukan refleksi terhadap prosesproses yang telah dilakukan dan membuat kesimpulanhendaknya dilaksanakan dengan melibatkan siswa untuk menguatkan pemahaman siswa terhadap materi yang telah dipelajari.

3. Penggunaan alat peraga atau media pembelajaran dapat membatu guru dalam memberikan permasalahan yang kontekstual bagi siswa.

\section{DAFTAR PUSTAKA}

Shoimin, A. 2014. 68 Model Pembelajaran Inovatif dalam Kurikulum 2013. Yogyakarta: Ar-Ruzz Media

Slameto. 2010. Belajar dan Faktor-Faktor yang Mempengaruhi. Jakarta: Rineka Cipta

Sudjana, N. 2013. Penilaian Hasil Proses Belajar Mengajar. Bandung: PT Remaja Rosdakarya

Wiriaatmadja, R. 2010. Metode Penelitian Tindakan Kelas. Bandung: PT Remaja Rosdakarya 